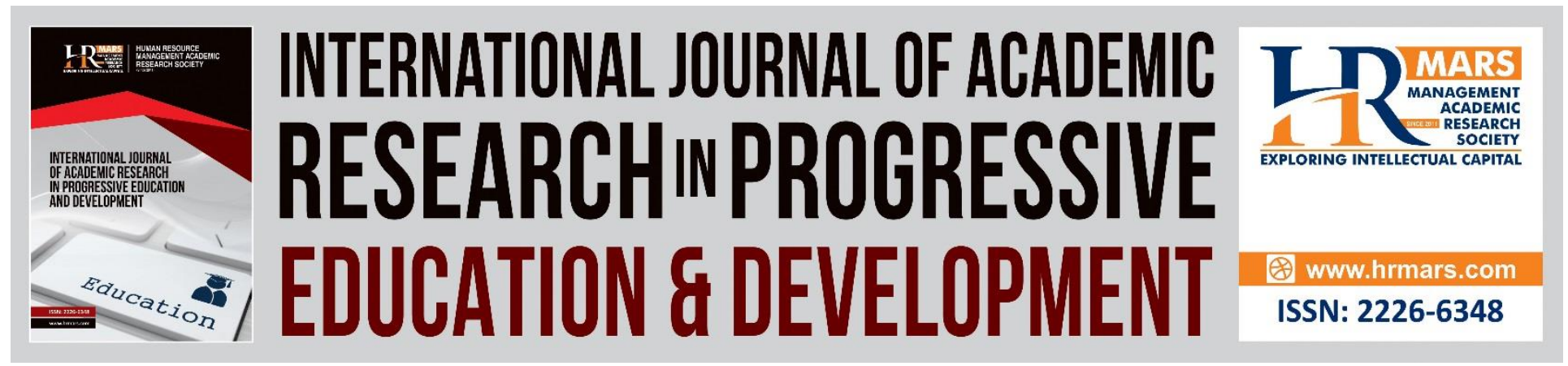

\title{
Teacher Leadership: Concept and Framework
}

\section{Nor Lizana Kamaruzaman, Khalip Musa, Zahari Hashim}

To Link this Article: http://dx.doi.org/10.6007/IJARPED/v9-i2/7628

DOI:10.6007/IJARPED/v9-i2/7628

Received: 11 April 2020, Revised: 13 May 2020, Accepted: 16 June 2020

Published Online: 29 July 2020

In-Text Citation: (Kamaruzaman, Musa, \& Hashim, 2020)

To Cite this Article: Kamaruzaman, N. L., Musa, K., \& Hashim, Z. (2020). Teacher Leadership: Concept and Framework. International Journal of Academic Research in Progressive Education and Development. 9(2), 574587.

Copyright: (C) 2020 The Author(s)

Published by Human Resource Management Academic Research Society (www.hrmars.com)

This article is published under the Creative Commons Attribution (CC BY 4.0) license. Anyone may reproduce, distribute, translate and create derivative works of this article (for both commercial and non-commercial purposes), subject to full attribution to the original publication and authors. The full terms of this license may be seen at: http://creativecommons.org/licences/by/4.0/legalcode

\section{Vol. 9(2) 2020, Pg. 574 - 587}

Full Terms \& Conditions of access and use can be found at http://hrmars.com/index.php/pages/detail/publication-ethics 


\title{
LR \\ INTERNATIONAL JOURNAL OF ACADEMIC \\ RESEARCHINPROGRESSIVE \\ EDUCATION \& DEVELOPMENT

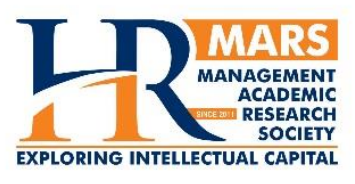 \\ INTERNATIONAL JOURNAL
OF ACADEMIC RESEARCH
IN PROGRESSIVE EAUCATION \\ IN PROGRESSIVE ENT
AND DEVELOPMENT \\ $\therefore$ \\ Teacher Leadership: Concept and Framework
}

\author{
Nor Lizana Kamaruzaman, Khalip Musa, Zahari Hashim \\ Faculty of Management and Economics, Sultan Idris Education University, Tanjung Malim, \\ Malaysia
}

\begin{abstract}
Teacher leadership has been widely discussed in terms of its definition, concept, frameworks, and models. Generally, teacher leadership encompasses the concept of power and influence. This paper has focused on four teacher leadership frameworks and models from Katzenmeyer and Moller (2001 \& 2009), York-Barr and Duke (2004), Muijs and Harris (2003), and Angelle (2017). A literature review was conducted on teacher leadership definitions and concepts, the frameworks and models were collated, and common aspects were identified. The paper also critically analysed the effectiveness in developing and implementing teacher leadership practices. This paper concludes with further understanding of recognising teachers as leaders throughout the school organisation. This paper aims to provide a reference for school leaders to adapt teacher leadership that is suitable for the schools' context and capacity.
\end{abstract}

Keywords: Distributed leadership, Empowerment, School improvement, School leadership, Teacher leadership.

\section{Introduction}

The concept of teacher leadership is now widely accepted and increasingly discussed among practitioners, researchers and educational scholars, particularly in the educational leadership field (Murphy, 2005). The growth of teacher leadership is attributed to teacher leadership's role in developing and improving schools. Teacher leadership aims to promote student learning and achievement, including to develop the school organisation altogether (Wenner \& Campbell, 2017). Besides, Nguyen, Harris and Ng (2019) asserted that teacher leadership seeks to enhance teaching quality, school effectiveness, and student learning. Wenner and Campbell (2017) argued that in working towards change and school improvement, teacher leaders' roles transcend the classroom walls. Among the roles outside the classroom include helping other teachers, providing professional development programs for other teachers through professional learning communities (PLC), and getting involved in policy and decision-making at certain levels in school. Thus, teacher leadership is seen as leadership across school boundaries (Muijs, Chapman, \& Armstrong, 2013).

The trend towards more collaboration in development for both within the school setting and between schools has created an environment that is more responsive to the teacher leadership concept (Muijs \& Harris, 2003). Teacher leadership is an effective way of building 
collective capacity to ensure and sustain a school and its system transformation (Harris, 2015). The teacher leadership concept is powerful because of its ability to improve teachers' morale and quality of their working life through greater engagement and collaboration (Frost \& Harris, 2003). Besides that, teacher leadership empowers teachers as teachers are encouraged to disseminate good teaching practices, and initiatives thus increase teacher empowerment (Muijs \& Harris, 2006). Being change agents, teachers play a central role in influencing students. Therefore, teachers must upgrade their knowledge and skills to increase their students' outcomes that can be facilitated through teacher leadership. Furthermore, teachers' roles in delivering lessons, sharing their knowledge and expertise can influence school improvement, which leads to the sustainability of the school's performance. Hence, this paper aims to:

- analyse and review various concepts, frameworks, and models used to measure teacher leadership.

- summarise the common aspects in the analysed teacher leadership framework and models.

\section{Definition and Concept of Teacher Leadership}

There are various definitions of teacher leadership (Harris \& Muijs, 2002). York-Barr and Duke (2004) defined teacher leadership as a process carried out by teachers, both individually and in groups, in influencing peers, principals, and other school members to improve the quality of teaching and learning for better student learning outcomes. This conceptualisation emerged from their systematic study of teacher leadership literature, which contributed to an overall conceptual structure (Hairon, Goh, \& Chua, 2015). Meanwhile, Katzenmeyer and Moller (2009) defined teacher leadership as teachers who can lead inside and outside the classroom, contribute to the community of teachers and leaders, motivate others to improve their teaching practice and accept responsibility as a leader to achieve the outcomes of leadership. The definition furthers with teacher leadership promoting new teaching methods, knowledge and skills sharing, and being the members of school task forces for school improvements.

Additionally, teacher leadership highlights the ability to create a comfortable and motivating learning environment (Katzenmenyer \& Moller, 2001). Meanwhile, Baker-Doyle (2017) stated that teacher leadership focuses on actions that transcend the teacher's formally assigned roles, such as sharing practices and making changes. The definition of teacher leadership also reflects the teacher's attitude, who continuously seek to enhance their knowledge and skills, including frequently reflecting and working collaboratively with the school community to improve both within and outside the classroom (Mahaliza, Jamal@Nordin, \& Yuet, 2018).

\section{Teacher Leadership and Distributed Leadership}

Based on previous research, teacher leadership is characterised by individual school setting practices (Angelle \& Schmid, 2007). The teacher leadership concept can be based on distributed leadership theory and its dimensions, which will be explained further with the teacher leadership concept. (Harris \& Spillane, 2008; Marlia \& Yahya, 2016). In distributed leadership, leadership roles are not restricted to a specific individual but include anyone in the organisation (Hargreaves, 2001). Similarly, teacher leadership incorporates many individuals within the organisation who share a common goal to achieve the school's success (Azhar, 2016; Muijs \& Harris, 2007). 
Therefore, in teacher leadership with distributed leadership, every teacher has the ability and opportunity to contribute to the school's growth and change.

Distributed leadership is a leadership practice which emphasises on capacity building that shifts from a structure of control to a structure that encourages learning and achievement at all levels in the organisation (Harris \& Lambert, 2003). Distributed leadership also emphasises the maximisation of intellectual and social capital (Hargreaves, 2001). Unlike universal leadership principles, distributed leadership stresses collaboration and collective responsibility. Similarly, in teacher leadership, there is a redistributed of power in schools that shift from hierarchical control to peer control (Nafia \& Suyatno, 2020). To further support this, Gronn (2000), one of the leading scholars in distributed leadership, asserted that the leadership characteristics of distributed leadership are somewhat emergent than a fixed phenomenon. Thus, this concept shows that teachers will always have the opportunity and potential to become leaders (Muijs \& Harris, 2006).

There are three key factors that relate to distributed leadership theory with the teacher leadership concept. Firstly, in distributed leadership, the activities of several groups of people who work together towards instructional change in a school are integrated. Secondly, there is social distribution in teacher leadership, whereby several individuals hold the leadership role, and the interaction of several leaders reflects how the leadership task is performed. Lastly, there is interdependency involved in teacher leadership which represents how various leaders share responsibility in various roles (Muijs \& Harris, 2003).

\section{Teacher Leadership and Teacher Empowerment}

York-Barr and Duke (2004) asserted that teacher leadership is reflected in teacher agency and teacher empowerment which is also one of the distributed leadership dimensions (Muijs \& Harris, 2003). Azhar, Ramli, Zaidatol Akmaliah, and Soaib (2016) refer to teacher leadership based on the agency that can be shared, distributed and enables each member of the organisation to lead. The teacher empowerment concept emphasises on collective actions, autonomy, and shared agency whereby the distributed leadership theory is translated (Azhar et al., 2016). To further support this, scholars have asserted that the distribution of power from hierarchy to peer control leads to the concept of empowerment which has been emphasised in teacher leadership (Heck \& Hallinger, 2009; Vlachadi \& Ferla, 2013). Since teacher leadership is conceptualised as a collection of jointly performed activities and practices (Muijs and Harris, 2007), relationships and interactions among school members are fundamental to teacher leadership. Thus, teacher leadership is strongly related to distributed leadership of empowerment when interactions and activities are concerned.

Based on teacher empowerment concept, a paradigm shift is seen in teacher leadership whereby instead of the people at the top of the hierarchy, teachers have the opportunity to make crucial decisions on matters concerning teaching and learning since they work closely with the students (Terry, 2017). Previous research has also indicated that when teachers are empowered to take on leadership roles, they feel motivated to perform better and are more satisfied with their job. Thus, empowered teachers will increase their self-worth and their intention to stay in their teaching career (Katzenmeyer \& Moller, 2001). Besides, the distribution of leadership throughout the school and the empowerment of teachers to become leaders lead to improved students' outcomes (Harris \& Muijs, 2002). In teacher leadership, teachers are individually 
empowered, and school management is brought to the teachers' level (York-Barr \& Duke, 2004). Hence, when teachers are empowered to take actions and disseminate good practices, teacher leadership helps to contribute to school improvement (Muijs \& Harris, 2007).

\section{Teacher Leadership and Influence}

Teacher leadership is also conceptualised in terms of influence (Katzenmeyer \& Moller, 2001; York-Barr \& Duke, 2004). Teachers' influence reflects the characteristics of teacher professionalism in the classroom that aims to effectively produce and improve students learning outcomes (Murphy, 2005). Frost (2012) argued that teachers must possess the ability and readiness to influence, guide, or manage their students to achieve their learning objectives. Besides, teacher leadership also includes influencing fellow teachers, students, and other school stakeholders either individually or collectively in the direction of common goals concerning teaching and learning improvements (Hairon et al., 2015; Murphy, 2005; Terry, 2017). Since teacher leaders influence other fellow teachers to improve their teaching practices, teacher leaders are also perceived as the change agents (Cooper et al., 2016). Furthermore, Wasley (1991) described teacher leadership as the ability to encourage colleagues to change or to do something they cannot do without having leadership skills. Thus, teacher leadership can be seen as a change mechanism where teachers are the primary agents and become the sources of development and innovation (Snoek, Enthoven, Kessels, \& Volman, 2015).

\section{Teacher Leadership and Roles and Responsibilities}

Teacher leaders hold a variety of roles and responsibilities, depending on the school context. Nevertheless, most researchers assert that the roles and responsibilities of teacher leaders include the roles within and outside the classroom that affect teachers' teaching practices (Cooper et al., 2016; Flood \& Angelle, 2017). Wenner and Campbell (2017) on their review of the theoretical and empirical basis of teacher leadership, stated that teacher leaders perform their primary teaching duties in the classroom while simultaneously assuming leadership roles outside the classroom. Teacher leadership also mediates the relationship between principal and student outcomes (Flood \& Angelle, 2017).

Moreover, teacher leaders may play both formal and informal roles in teacher leadership (Harris, 2003). Formal roles involve particular positions such as department head or subject coordinator, which separate the teacher from being the leader in the classroom. Some of the regarded formal positions are mentor teacher, coach, specialist, and head of department (Neumerski, 2012). On the other hand, informal roles include classroom-based tasks or activities such as planning, communication of the objectives, and regulating activities (Harris, 2003). Teacher leaders are also involved in external programs whereby they engage in a variety of formal and informal meetings (Muijs \& Harris, 2007). In this instance, teacher leaders guide other teachers through involvement and collaboration in various instructional activities and programs (Marlia \& Yahya, 2016). While focusing on student learning and continuously improving themselves through life-long learning, teacher leaders also utilise their communication skills, particularly in presentation and facilitation skills. Besides, teacher leaders also work in integrity and are effective in planning, managing, building and sustaining relationships as well as involving their colleagues to work towards a shared vision (Angelle \& Dehart, 2011). 
According to Harris and Muijs (2004), there are two main principles to foster teacher leadership characteristics. The first principle refers to teachers being responsible for achieving the goal established by the school, influence students to achieve classroom goals, assist students in obtaining good results, and guide their colleagues without the direction from the superior. The second principle concerns the collaboration and collegiality among fellow teachers and school citizens working towards school achievement and improvement (Harris, 2005). Additionally, Wills (2015) identified three main areas of teacher leadership practice in her study, which are teaching competence, collaboration with colleagues, and participation in decision-making. In a teacher leadership context, teachers develop their expertise by working collaboratively, thus establishing a collective leadership and school culture, which is contrary to the traditional notions of leadership (Boles \& Troen, 1994).

\section{Teacher Leadership Framework and Model}

This paper will discuss four frameworks of teacher leadership identified in previous literature, which are Teacher Leadership Model by Katzenmeyer and Moller (2001 \& 2009), Teacher Leadership Framework by York-Barr and Duke (2004), Teacher Leadership Model by Muijs and Harris (2003), and Four-Factor Model of Teacher Leadership by Angelle (2017).

\section{Teacher Leadership Model by Katzenmeyer and Moller (2001 \& 2009)}

Katzenmeyer and Moller (2001) defined teacher leadership as teachers who lead inside and outside the classroom, contribute towards the teacher's community and school leaders, influence others to improve practices, and accept responsibilities to achieve success. Developing teachers with the potential to become leaders requires teachers to understand themselves before collaborating with other teachers and the school leaders. Therefore, teachers need to understand and master the necessary skills to become teacher leaders and practice these skills within their working environment (Norashikin, Ramli, \& Foo, 2015).

Based on their research on 5000 teachers, Katzenmneyer and Moller (2001) identified seven dimensions that promote teacher leadership in schools, which are the developmental focus, recognition, autonomy, collegiality, participation, open communication, and positive environment. In the developmental focus dimension, teachers are encouraged to improve their knowledge and skills as well as to promote other teachers to learn. In this dimension, teachers are given the necessary assistance, coaching, and guidance. The second dimension is recognition, whereby teachers are respected and appreciated for their contribution and professional tasks that they have done or performed. Resultantly, the recognition dimension leads to a positive climate of love and respect amongst teachers. In the autonomy dimension, teachers are encouraged to take steps for school improvement and innovation. To achieve in autonomy dimension, teachers are provided with sufficient resources and eliminating any barriers to teacher leadership. The fourth dimension, which is collegiality, refers to teachers' collaboration in instructional strategies and students' affairs. For instance, collegiality can be seen in teachers' discussion on teaching strategies, sharing resources, and peer observation in the classrooms.

Continuing, the participation dimension refers to teachers being actively involved in decision- making and providing inputs on essential matters. Teachers are also involved in the selection of heads of department or team leaders. In terms of open communication dimension, 
teachers practice open and honest communication among themselves, such as being free to express their feelings and opinions, and they are always aware of things happening in school. Finally, the positive environment dimension is where the teachers feel satisfied with their working environment and the people they work with. Teachers feel a sense of respect from their colleagues, students, administrators, as well as parents. Based on these seven dimensions, Katzenmeyer and Moller (2001) created an instrument called The Teacher Leadership School Survey (TLSS).

In 2009, Katzenmeyer and Moller proposed seven dimensions of teacher leadership. Researchers in teacher leadership have widely used this model. Those dimensions are selfawareness, leading change, communication, diversity, instructional policy and leadership, continuous improvement, and self-organisation. The first dimension, self-awareness, refers to the aspect where teachers have a precise self-image in terms of strengths, values, philosophy, and conduct (Katzenmeyer \& Moller, 2009; York-Barr \& Duke, 2004). Leading change, on the other hand, refers to the commitment of teachers in using practical approaches to foster meaningful change (Katzenmeyer \& Moller, 2009).

In the continuous improvement dimension, this dimension refers to the involvement of teachers with their colleagues in the planning, implementing, and reviewing the school system that leads to change and school improvement. Therefore, the leadership of teachers does affect initiatives for school reform (Fairman \& Mackenzie, 2012; York-Barr \& Duke, 2004). In the communication aspect, teachers display effective listening skills, oral communication, presentation skills, and written communication expressions. Correspondingly, communication skills are essential as a means of building a good rapport among teachers (York-Barr \& Duke, 2004). Therefore, teachers need to possess good communication skills such as listening effectively, writing efficiently, and being able to express meaningful language to build good relationships with the school community.

Subsequently, the diversity dimension refers to the teacher's ability to maintain good social ties within the school community and be respectful to other teachers' different views or perspectives (Fairman \& Mackenzie, 2012; York-Barr \& Duke, 2004). To support this, teachers' pedagogical qualifications and knowledge are critical to the development and maintenance of school improvement (Hallam, Chou, Hite, \& Hite, 2012) thus teachers that show respect and react to different viewpoints are essential to ensure school improvement (Katzenmeyer \& Moller, 2009). In instructional policy and leadership aspects, teachers acquire and utilise their professional knowledge and skills to offer students and adults with effective learning opportunities (Katzenmeyer \& Moller, 2009; York-Barr \& Duke, 2004). Hence, teachers use their teaching skills to improve organisational performance (Fairman \& Mackenzie, 2012).

Lastly, continuous improvement and self-organisation strongly relate to teachers as change agents. Since teachers are regarded as change agents, teachers should have high selfesteem in ensuring school improvement and effectiveness (York-Barr \& Duke, 2004). When teachers have self-organisation, teachers can balance between professional and personal matters in carrying out their tasks. Moreover, self-organised teachers possess the right attitude, competence, and motivation to perform their duties (Katzenmeyer \& Moller, 2009). This Teacher Leadership Model led to an instrument called Teacher Leadership Self-Assessment (TLSA) that was developed by Katzenmeyer and Moller (2009) to measure these dimensions. 


\section{Teacher Leadership Framework by York-Bark and Duke (2004)}

York-Barr and Duke (2004) produced the Teacher Leadership Framework based on literature review from 1980 until 2004. The framework consisted of four categories, which are benefits of employee participation in teacher leadership, teaching and learning expertise, acknowledgement, opportunities, and rewards for accomplished teachers, and lastly, benefits to students. This framework was developed based on the need to empower teachers as a means to optimise the school's operation for better outcome contributions. Thus, if the motivation of teacher leaders are sustained, teachers can create more opportunities for learning and improving instructional practices that will lead will better students' learning outcomes (Tsai, 2017). Therefore, teacher leadership is vital for education reform.

York-Barr and Duke (2004) emphasised on the theory of action in the Teacher Leadership Framework. In this theory, teacher leadership stems from the teacher themselves, the type of work that they do, and the context of the school. Thus, teacher leaders play a variety of roles with individuals, teams, and the entire system to enhance teaching and learning for students (York-Barr \& Duke, 2004). Thus, York-Barr and Duke (2004) developed a framework that comprised seven components, which are the characteristics of teacher leadership, the types of leadership work, the work climate or conditions that support teacher leadership, the way teachers lead, the target of the leadership influence they practised, intermediary results of changes in instructional practices, and student learning (Nafia \& Suyatno, 2020; Hairon et al., 2015).

Additionally, York-Barr and Duke (2004) identified five essential themes of teacher leadership in their review. The first theme is the leadership of teachers outside the classroom, teacher leaders to encourage professional learning in their schools, the involvement of teacher leaders in policy or decision-making in certain school management level, teacher leaders to improve student learning and outcome as the final objective, and the effort of teacher leaders towards change and improvement for the school as a whole.

\section{Teacher Leadership Model by Muijs and Harris (2003)}

Muijs and Harris (2003) recommended four dimensions in the roles of teacher leadership. The first dimension is the teacher leaders' brokering role in ensuring that linkages are established between schools and to maximise opportunities for meaningful teacher development. In other words, this dimension refers to the way teachers work across the school structure to create social linkages among the school community. The second dimension focuses on participative leadership, whereby teachers work together in teaching strategies. In this dimension, teacher leaders will encourage other teachers to work together and promote a more cooperative way of working. Additionally, teachers will collaborate with colleagues to develop better practices and guide teachers towards a common objective. Thus, the second dimension shows that all teachers are involved in school change and development with a sense of ownership.

The third dimension emphasises the teachers' role as a mediator, whereby teachers are the essential resources for information and expertise in instructional practices because of their exceptional instructional skills. When necessary, teachers would depend critically on additional resources and skills as well as searching for external assistance. The final dimension refers to teacher leaders' role as an instructional leader to create and develop close relationships with 
other teachers in the implementation of reciprocal learning (Harris, 2015). From this framework, it can be concluded that teacher leaders are expert teachers who spend most of their time in the class, but at different times take on leadership roles following the principles of formative leadership (Muijs \& Harris, 2003).

\section{Four-Factor Model of Teacher Leadership by Angelle (2017)}

The teacher leadership model by Angelle (2017) combined several factors to measure the level of teacher leadership in schools. The first three factors were developed based on previous research conducted by Angelle and DeHart (2016). The three-factor model by Angelle and DeHart (2016) formed a leadership dimension to explain teacher leadership. The first factor is Sharing Expertise (SE) that involves teachers' perception towards their pedagogical skills and classroom management, as well as teachers' willingness to share their expertise with colleagues (Angelle, 2017). The next factor is Sharing Leadership (SL) which refers to reciprocal relationships between the principal and the teachers in school. There are two sub-factors for Sharing Leadership, which are Sharing Leadership Opportunities (SLO) and Sharing Leadership Engagement (SLE). The subfactor SLO depends on the principal's attitude in providing teachers with the opportunity to be involved in leadership practices in school. In contrast, SLE reflects the teachers' tendency to assume responsibilities and leadership tasks.

The third factor is Supra Practitioner (SP) which refers to teachers' perceptions towards their willingness to perform tasks and responsibilities that transcend the roles assigned to them. Angelle (2017) added the fourth factor that considers the schools' context which is the principal's hierarchy and seniority that affect the practice of teacher leadership. Finally, the last element, which is Principal Selection (PS) focuses on the principal's control of teachers' participation in leadership activities.

\section{Findings}

Based on the review of the four teacher leadership frameworks and models, this paper has identified 11 aspects in teacher leadership. The aspects are teachers' roles beyond the classroom, roles and expertise in instructional practices, autonomy or empowerment given to teachers, teachers' ability to influence other teachers for improvement, collaboration through working together and sharing practices, teachers' professional development, teacher's participation and engagement in leadership activities, and contribution to the community, teacher's work and performance recognition, working environments, and improve student outcomes. 
INTERNATIONAL JOURNAL OF ACADEMIC RESEARCH IN PROGRESSIVE EDUCATION AND DEVELOPMENT

Vol. 9, No. 2, 2020, E-ISSN: $2226-6348$ @ 2020 HRMARS

To summarise, the four teacher leadership frameworks and models have emphasised on common aspects, as shown in the table below:

\begin{tabular}{|c|c|c|c|c|}
\hline \multirow[t]{2}{*}{ Aspects } & $\begin{array}{l}\text { Teacher } \\
\text { Leadership } \\
\text { Model by } \\
\text { Katzenmeyer }\end{array}$ & \multirow[t]{2}{*}{$\begin{array}{l}\text { Teacher } \\
\text { Leadership } \\
\text { Framework by } \\
\text { York-Bark and } \\
\text { Duke (2004) }\end{array}$} & \multirow[t]{2}{*}{$\begin{array}{l}\text { Teacher } \\
\text { Leadership } \\
\text { Model by Muijs } \\
\text { and Harris } \\
\text { (2003) }\end{array}$} & \multirow[t]{2}{*}{$\begin{array}{l}\text { Four Factor } \\
\text { Model of } \\
\text { Teacher } \\
\text { Leadership by } \\
\text { Angelle (2017) }\end{array}$} \\
\hline & $\begin{array}{l}\text { and Moller } \\
\text { (2001 \& 2009) }\end{array}$ & & & \\
\hline
\end{tabular}

\begin{tabular}{|c|c|c|c|c|}
\hline $\begin{array}{l}\text { Roles beyond } \\
\text { classroom }\end{array}$ & v & v & v & v \\
\hline $\begin{array}{lr}\text { Roles and } \\
\text { expertise in } \\
\text { instructional } \\
\text { practices }\end{array}$ & v & $\mathrm{v}$ & $\mathrm{v}$ & v \\
\hline $\begin{array}{l}\text { Autonomy / } \\
\text { empowerment }\end{array}$ & $\mathrm{V}$ & $\mathrm{v}$ & $\mathrm{v}$ & 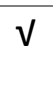 \\
\hline $\begin{array}{ll}\text { Influence } & \text { on } \\
\text { others } & \text { to } \\
\text { improve } & \end{array}$ & $\mathrm{V}$ & $\mathrm{v}$ & $v$ & \\
\hline Collaboration & $\mathrm{V}$ & $\mathrm{v}$ & $\mathrm{v}$ & $v$ \\
\hline $\begin{array}{l}\text { Professional } \\
\text { development }\end{array}$ & $\mathrm{V}$ & $\mathrm{V}$ & $\mathrm{V}$ & \\
\hline $\begin{array}{l}\text { Participation and } \\
\text { engagement }\end{array}$ & v & $\mathrm{v}$ & $\mathrm{v}$ & v \\
\hline $\begin{array}{l}\text { Contribution to } \\
\text { the community }\end{array}$ & v & v & v & \\
\hline Recognition & $\mathrm{V}$ & $\mathrm{v}$ & & \\
\hline $\begin{array}{l}\text { Work } \\
\text { environment }\end{array}$ & $\mathrm{V}$ & $\mathrm{V}$ & & \\
\hline $\begin{array}{l}\text { Improve student } \\
\text { outcomes }\end{array}$ & $\mathrm{v}$ & v & & \\
\hline
\end{tabular}

Table 1: Summary of common aspects identified in four teacher leadership frameworks and models.

\section{Conclusion}

This paper has studied the definition and concept underlying teacher leadership, including four frameworks and models of teacher leadership. Based on definition and concept, teacher leadership is a leadership model where power is distributed and authority is realigned within the organisation (Muijs \& Harris, 2006). Additionally, teacher leadership is conceptualised as teachers who assume leadership responsibilities outside the classroom. However, the notions and definitions of the term teacher leaders still differ widely (Wenner \& Campbell, 2017). Generally, teacher leadership can be concluded as the leadership roles of teachers both in and 
outside the classroom. Teachers are regarded as experts in teaching and learning practices as well as skilful in managing the learning climate in the classroom. At the same time, teachers become leaders outside the classroom by collaborating with colleagues to ensure student outcomes and school improvement. Teacher leadership also reflects upon modes of empowerment, agency, and collective action that are the core elements in distributed leadership theory.

This paper found that the teacher leadership frameworks and models consist of teachers' roles inside and outside the classroom, expertise in teaching and learning practices, professional development, collaboration, contribution to the community, and student learning. It helps future researchers in teacher leadership to explore more roles that a teacher leader can undertake to improve teaching practice as well as to improve student learning. Besides that, based on the teacher leadership models discussed, this paper has provided useful insights for school leaders to adapt teacher leadership model that is suitable according to their unique school contexts and capacity. Since the concept, definition, frameworks, and models of teacher leadership still vary, more empirical research is necessary to identify different teacher leadership models and approaches. Additionally, future studies are required to explore how teacher leadership can be best developed and improved as well as to investigate how teacher leadership contributes to school improvement.

\section{References}

Angelle, P. S. (2017). Leading beyond the classroom. International Studies in Educational Administration (Commonwealth Council for Educational Administration \& Management), 45(3), 101-107.

Angelle, P. S., \& Dehart, C. A. (2011). Teacher perceptions of teacher leadership: Examining differences by experience, degree, and position. NASSP Bulletin, 95(2), 141-160. https://doi.org/10.1177/0192636511415397

Angelle, P. S., \& Dehart, C. A. (2016). Comparison and evaluation of four models of teacher leadership. Research in Educational Administration \& Leadership, 1(1), 85-119.

Angelle, P. S., \& Schmid, J. B. (2007). School structure and the identity of teacher leaders: Perspectives of principals and teachers. Journal of School Leadership, 17(6), 771-799. https://doi.org/10.1177/105268460701700604

Harun, A. (2016). Hubungan kepemimpinan distributif pengetua dan kepemimpinan guru di sekolah menengah Zon Timur Semenanjung Malaysia. Universiti Putra Malaysia.

Baker-Doyle, K. J. (2017). How can community organisations support urban transformative teacher leadership? Lessons from three successful alliances. The Educational Forum, 81(4), 450-466. https://doi.org/10.1080/00131725.2017.1350242

Boles, K., \& Troen, V. (1994). Teacher leadership in a professional development school. In Annual meeting of the American Educational Research Association. New Orleans, LA.

Cooper, K. S., Stanulis, R. N., Brondyk, S. K., Hamilton, E. R., Macaluso, M., \& Meier, J. A. (2016). The teacher leadership process: Attempting change within embedded systems. Journal of Educational Change, 17(1), 85-113. https://doi.org/10.1007/s10833-015-9262-4

Fairman, J. C., \& Mackenzie, S. V. (2012). Spheres of teacher leadership action for learning. Professional Development in Education, 38(2), 229-246. 
INTERNATIONAL JOURNAL OF ACADEMIC RESEARCH IN PROGRESSIVE EDUCATION AND

DEVELOPMENT

Vol. 9, No. 2, 2020, E-ISSN: $2226-6348$ @ 2020 HRMARS

https://doi.org/10.1080/19415257.2012.657865

Flood, L. D., \& Angelle, P. S. (2017). Organizational influences of collective efficacy and trust on teacher leadership. International Studies in Educational Administration, 45(3), 85-99.

Frost, D. (2012). From professional development to system change: Teacher leadership and innovation. Professional Development in Education, 38(2), 205-227. https://doi.org/10.1080/19415257.2012.657861

Frost, D., \& Harris, A. (2003). Teacher leadership: towards a research agenda. Cambridge Journal of Education, 33(3), 479-498. https://doi.org/10.1080/0305764032000122078

Gronn, P. (2000). Distributed properties: A new architecture for leadership. Educational Management Administration \& Leadership, 28(3), 317-338. https://doi.org/10.1177/0263211X000283006

Hairon, S., Goh, J. W. P., \& Chua, C. S. K. (2015). Teacher leadership enactment in professional learning community contexts: Towards a better understanding of the phenomenon. School Leadership and Management, 35(2), 163-182.

https://doi.org/10.1080/13632434.2014.992776

Hallam, P. R., Chou, P. N., Hite, J. M., \& Hite, S. J. (2012). Two contrasting models for mentoring as they affect retention of beginning teachers. NASSP Bulletin, 96(3), 243-278. https://doi.org/10.1177/0192636512447132

Hargreaves, A. (2001). Emotional geographies of teaching. Teachers College Record, 103(6), 1056-1080. https://doi.org/10.1111/0161-4681.00142

Harris, A. (2003). Teacher leadership as distributed leadership: Heresy, fantasy or possibility? School Leadership and Management, 23(3), 313-324. https://doi.org/10.1080/1363243032000112801

Harris, A. (2005). Teacher leadership: More than just a feel-good factor? Leadership and Policy in Schools, 4, 201-219. https://doi.org/10.1080/15700760500244777

Harris, A. (2015). Teacher Leadership. International Encyclopedia of the Social \& Behavioral Sciences: Second Edition, 24, 60-63. https://doi.org/10.1016/B978-0-08-0970868.92135-4

Harris, A., \& Lambert, L. (2003). Building leadership capacity for school improvement. Philadelphia: Open University Press.

Harris, A., \& Muijs, D. (2002). Teacher leadership: A review of the research. National College for School Leadership, 1-5.

Harris, A., \& Muijs, D. (2004). Improving schools through teacher leadership. London: Open University Press.

Harris, A., \& Spillane, J. (2008). Distributed leadership through the looking glass. Management in Education, 22(1), 31-34. https://doi.org/10.1177/0892020607085623

Heck, R. H., \& Hallinger, P. (2009). Assessing the contribution of distributed leadership to school improvement and growth in Math achievement. American Educational Research Journal, 46(3), 659-689. https://doi.org/10.3102/0002831209340042

Katzenmeyer, M. H., \& Moller, G. V. (2001). Awakening the sleeping giant: Helping teachers develop as leaders. 2nd Ed. Thousand Oaks, CA: Corwin Press.

Katzenmeyer, M. H., \& Moller, G. V. (2009). Awakening the sleeping giant: Helping teachers develop as leaders. 3rd Ed. Thousand Oaks, CA: Corwin Press. 
Killion, J., \& Harrison, C. (2006). Taking the lead: New lead roles for teachers and school-based coaches. Oxford, OH: National Staff Development Council.

Mansor, M., Yunus, J., \& Yuet, F. K. C. (2018). Validity and reliability of the teacher leadership inventory in Malaysian educational context. International Journal of Academic Research in Progressive Education and Development, 7(3), 480-488. https://doi.org/10.6007/IJARPED/v7-i3/4566

Jamail, M., \& Don, Y. (2016). Praktis kepimpinan distributif dan komitmen terhadap organisasi berdasarkan kohort generasi guru. In International Seminar on Generating Knowledge Through Research, 1, 275-286. https://doi.org/10.21070/picecrs.v1i1.612

Muijs, D., Chapman, C., \& Armstrong, P. (2013). Can early careers teachers be teacher leaders? A study of second-year trainees in the Teach First Alternative Certification Programme. Educational Management Administration and Leadership, 41(6), 767-781. https://doi.org/10.1177/1741143213494188

Muijs, D., \& Harris, A. (2003). Teacher leadership-Improvement through empowerment? Educational Management and Administration, 31(4), 437-448. https://doi.org/10.1177/0263211X030314007

Muijs, D., \& Harris, A. (2006). Teacher led school improvement: Teacher leadership in the UK. Teaching and Teacher Education, 22(8), 961-972. https://doi.org/10.1016/j.tate.2006.04.010

Muijs, D., \& Harris, A. (2007). Teacher leadership in action. Educational Management Administration \& Leadership, 35(1), 111-134. https://doi.org/10.1177/1741143207071387

Murphy, J. (2005). Connecting teacher leadership and school improvement. California: Corwin Press.

Nafia, Z. I., \& Suyatno, S. (2020). The effect of teachers' leadership on students' motivation in AlIslam Tambakbayan Elementary School. Universal Journal of Educational Research, 8(5), 1907-1915. https://doi.org/10.13189/ujer.2020.080527

Neumerski, C. M. (2012). Rethinking instructional leadership, a review: What do we know about principal, teache, and coach instructional leadership, and where should we go from here? Educational Administration Quarterly, 1-38. https://doi.org/10.1177/0013161X12456700

Nguyen, D., Harris, A., \& Ng, D. (2019). A review of the empirical research on teacher leadership. Journal of Educational Administration, 58(1), 60-80. https://doi.org/10.1108/JEA-022018-0023

Smylie, M. A. (1995). New perspectives on teacher leadership. The Elementary School Journal, 96(1), 3-7.

Snoek, M., Enthoven, M., Kessels, J., \& Volman, M. (2015). Increasing the impact of a Master' s programme on teacher leadership and school development by means of boundary crossing. International Journal of Leadership in Education, 1-30. https://doi.org/10.1080/13603124.2015.1025855

Terry, P. M. (2017). Empowering teachers as leaders. National Forum Journals, 1-8.

Tsai, K. C. (2017). Development of the Teacher Leadership Style Scale. Social Behavior and Personality, 45(3), 477-490. https://doi.org/10.2224/sbp.5751 
Vlachadi, M., \& Ferla, M. (2013). Differentiation of teachers' and principals' engagement in distributed leadership according to their demographic characteristics. Journal of Education and Learning, 2(4), 19-30. https://doi.org/10.5539/jel.v2n4p19

Wasley, P. A. (1991). Teachers who lead: The rhetoric of reform and the realities of practice. New York: Teachers College Press.

Wenner, J. A., \& Campbell, T. (2017). The theoretical and empirical basis of teacher leadership: A review of the literature. Review of Educational Research, 20(10), 1-38. https://doi.org/10.3102/0034654316653478

Wills, A. (2015). A case study of teacher leadership at an elementary school. Unpublished Certificate of Advanced Study Thesis. Sacred Heart University. Retrieved from http://digitalcommons.sacredheart.edu/edl/6

York-Barr, J., \& Duke, K. (2004). What do we know about teacher leadership? Findings from two decades of scholarship. Review of Educational Research, 74(3), 255-316. https://doi.org/10.3102/00346543074003255 